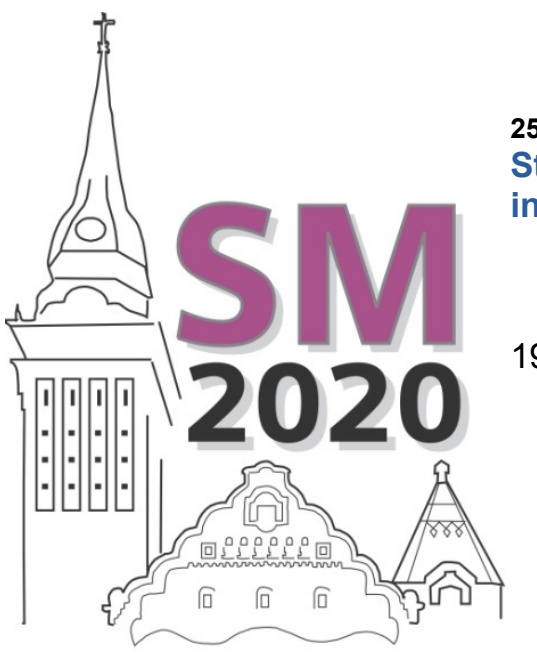

DOI: 10.46541/978-86-7233-386-2_10

25th International Scientific Conference

Strategic Management and Decision Support Systems

in Strategic Management

$19^{\text {th }}$ May, 2020, Subotica, Republic of Serbia

Roland SCHMUCK

Pécs, Hungary

schmuck.roland@ktk.pte.hu

\title{
THE QUALITY ASSURANCE OF STRATEGIC MANAGEMENT CONSULTING FIRMS
}

\begin{abstract}
Defining quality in most institutions are clear and easy to do. However quality management is hard to define in case of services because services do not have such generally common, measureable and comparable features like products. In case of services without exact outcomes are even harder to define quality. Strategic management consulting is such a service. Strategic consultants help organizations so solve complex, messy problems. It is very hard to define quality in this case. There is no one best way to manage quality in this case. The goal of this paper is to clarify how quality management can work in such circumstances in the strategic management consulting services industry.

The paper is based on literature research and the author's own experiences as a certified ISO 9001 auditor. This gives a quality standard view of the paper, however other aspects are discussed as well.

Strategic management consulting firms have to build trust. This is an important reason to concentrate on quality. Consulting companies can use several methods to increase their service quality. Mostly soft methods can be used because of the limited availability of possible statistical data. The most typical soft methods are shown in this paper.

Many of the consulting firms operate ISO 9001 standard-based quality management systems or TQM in their own organizations. Back in time this was a different story. In the 1980s consulting firms rather worked on their clients' quality concerns not on their own. This has change a lot since that. Nowadays there is a high need of quality operation with reduced costs that the consulting firms themselves also operate quality management systems. These systems can reduce their costs as well by making better decisions and decreasing the cost of bad quality such as faulty fulfillment and guarantee costs. The features of the ISO 9001 standard are shown in this paper regarding the management consulting sector.

Quality is becoming a major issue for consulting companies to get new contracts. This is an industry based mainly on trust because the outcome of the service is not immediate and can hardly be measured. Consulting companies should not only keep the technical standards but have to satisfy the customers' requirements to provide a quality service.
\end{abstract}

Keywords: strategy, management, consulting, quality assurance, quality management

\section{INTRODUCTION}

Defining quality in most institutions are clear and easy to do. However quality management is hard to define in case of services because services do not have such generally common, measureable and comparable features like products. In case of services without exact outcomes are even harder to define quality. Business consulting is such a service. Business consultants help organizations so solve complex, messy problems. It is very hard to define quality in this case. There is no one best way to manage quality in this case. The goal of this paper is to clarify how quality management can work in such circumstances in the business consulting services industry.

The paper is based on literature research and the author's own experiences as a certified ISO 9001 auditor. This gives a quality standard view of the paper, however other aspects are discussed as well. The paper is mainly theoretical. 


\section{QUALITY OF SERVICES}

Quality is not only privilege of luxurious services. It is becoming a major issue in most of today's organizations. Nowadays the customers demand high quality service at a low cost. (Vörös 2010)

Quality can be defined in several ways. The most common dimensions are the following:

1. compliance with standards,

2. satisfy the current demands of customers,

3. acceptable rate of price and costs,

4. satisfy the demands of future customers (Sziszkov 1975).

These definitions can well define the quality of products or services in general terms.

There are eight dimensions of quality of products (Garvin 1987) but these can be interpreted to products only and not to services. Zeithaml et al (1985) defined ten dimensions of the quality of services:

1. Reliability: involves consistency of performance and dependability;

2. Responsiveness concerns the willingness or readiness of employees to provide service;

3. Competence means possession of the required skills and knowledge to perform the service;

4. Access involves approachability and ease of contact;

5. Courtesy involves politeness, respect, consideration, and friendliness of contact personnel (including receptionists, telephone operators, etc.);

6. Communication means keeping customers informed in language they can understand and listening to them;

7. Credibility involves trustworthiness, believability, honesty. It involves having the customer's best interests at heart;

8. Security is the freedom from danger;

9. Understanding/Knowing the customer involves making the effort to understand the customer's needs;

10. Tangibles include the physical evidence of the service.

These dimensions can help to understand the quality of services and help to manage their quality. By the research of Viadiu et al (2002) the most important dimension in consulting is reliability. Reliability makes customer more satisfied which helps higher profit and lower employee turnover. The later one is very important in case of business consulting. As it is a high knowledge industry the main value of the company is in the employees.

The widely known and used ISO 9001 quality management system can be implemented in case of service providers to assure the quality of their service. The standard itself is very general which makes it easy to customize to the requirements of organizations (Schmuck 2010).

\section{BUSINESS CONSULTING}

Consulting has many definitions but the two main approaches are the following (Kubr 2002). The first approach has a functional view: " $\ldots$ any form of providing help on the content, process or structure of a task or series of tasks, where the consultant is not actually responsible for doing the task itself but is helping those who are." (Steele 1975 p. 3.). The second approach has a view of consulting as a professional service: "You are consulting any time you are trying to change or improve a situation but have no direct control over the implementation ... Most people in staff roles in organizations are really consultants even if they don't officially call themselves consultants." (Block 2000 p. XVII and 2.). This later definition may seem different than the traditional view of consultancy, but it is proofed by practices. Jack Welch, CEO of General Electric believed that all division has to develop their own consulting skills to be able to cope with problems themselves (Miller \& Whitney 2003). In any of these definitions consultants solve problems and help managing the change within the organization. Internal accounting of companies and their control systems facilitate the implementation of the proposed strategy (Ittner \& Larcker 1997). McKinsey \& Company's purpose is not be a consulting company, but to help organizations become more successful which may include other methods than traditional consulting services (Collins \& Porras 1996).

The 'product' of consultant companies is the intellectual property of their consultants which is actually the accumulation of special skills and knowledge. Consulting is a service where consultants stimulate their clients to make changes. No one knows about the future success, but the previous knowledge of consultants can give some guarantee on good ideas and proposals. Consultants should be ready to handle unexpected situations in strong cooperation with the organization. Consultant is a helper hand for the organization (Biswas \& Twitchell 2006) When choosing the right consultant company it is important to be sure that the consultant company has enough capacity to successfully complete the work (Crăciun 2013).

Problems, that consultants solve can be hard or soft (also called messy) problems. The messy problems are harder to solve, they don't have limits and the process to solve them is unknown. Hard problems are much easier to define: these are limited problems with known resources and predefined goals (Senior-Swailes 2016). Consultants have roles solving any of these problems. Solving messy problems is a much harder work and the results are unknown. 
Clients usually choose their consultants based on the following:

1. Integrity and professional ethics the consulting company,

2. Professional competence;

3. Problem solving approach;

4. Capacity to deliver on time;

5. Ability to deploy resources;

6. Consultant's image and reputation (Svasta 2010).

\section{THE ROLE OF STRATEGIC MANAGEMENT CONSULTING}

Consultants who concern themselves with issues like basic goals or mission, business policy and strategy, planning, structuring and control of an organization are strategic or general management consultants. They are different than those consultants who consult in a specialized functional area like finance or marketing (Kubr 2002). Companies with deterioration results, in crisis or near crisis may need the help of such consultants. In these cases the top management may be out of ideas where the company is heading and what to do. In other cases the management may have the goals but they are unable to implement the strategies (Kubr 2002).

Strategic consulting is part of management consulting, so the features of management consulting applies to this type of consulting as well:

- Management consulting should be done on base of a contract;

- Consultants are independent of that company which receives the consulting activity;

- Consultants should not decide on their ideas and proposals;

- Consultants should only cooperate in implementing their proposals if they are asked to do that (Hoványi 1997).

Table 1. Typical goals of strategic planners

\begin{tabular}{|c|c|}
\hline Goal and function of strategic planning & Description \\
\hline Proposal & $\begin{array}{l}\text { Informing the top management of proposed strategic steps } \\
\text { with the help of analysis. }\end{array}$ \\
\hline Determinate course line & $\begin{array}{l}\text { Facilitate competitive short-, middle-, or long-term strategies } \\
\text { with the help of company ideas and analysis. It can be } \\
\text { implemented through three methods: top-down, down-top, } \\
\text { hybrid of the two. }\end{array}$ \\
\hline Motivational paradigm shift & $\begin{array}{l}\text { Raising provocative business ideas motivating managers to } \\
\text { prescind ordinary strategies and tactics. }\end{array}$ \\
\hline Analyse strategic business information & Analysing information to help the work of top management. \\
\hline Encouragement and motivation & $\begin{array}{l}\text { Persuasion of the affected groups within the organization and } \\
\text { motivate them to use business ideas. }\end{array}$ \\
\hline Provide intellectual property to business decisions & $\begin{array}{c}\text { Creating of databases and make analyses to support } \\
\text { management decisions in mainly those cases which are } \\
\text { important in a strategic view (e.g. company acquisitions and } \\
\text { fusions). }\end{array}$ \\
\hline "Think tank" or inexhaustible storehouse of ideas & $\begin{array}{c}\text { Creating of analyses and definition of statements to solve } \\
\text { business problems. }\end{array}$ \\
\hline
\end{tabular}

Source: Arnold \& Bernstein 2006: 94.

Strategic management consultants need a complex view of the organization, understanding its processes, knowing its environment and its resources. This makes strategic management consulting a complex consulting work. (Moussetis 2011) Consultants need to use change management techniques. Any consultant service include changes in the organization - let it be strategic plan or business process reengineering (Maria \& Little 2006). There is usually no guarantee that the proposals of the consultant will work. However Biech suggests that consultants should offer 100\% money-back guarantee for the work done (Biech 2006).

Strategic consultant concentrates on the five main subjects of the strategic consulting progress as can be seen in Figure 1. 


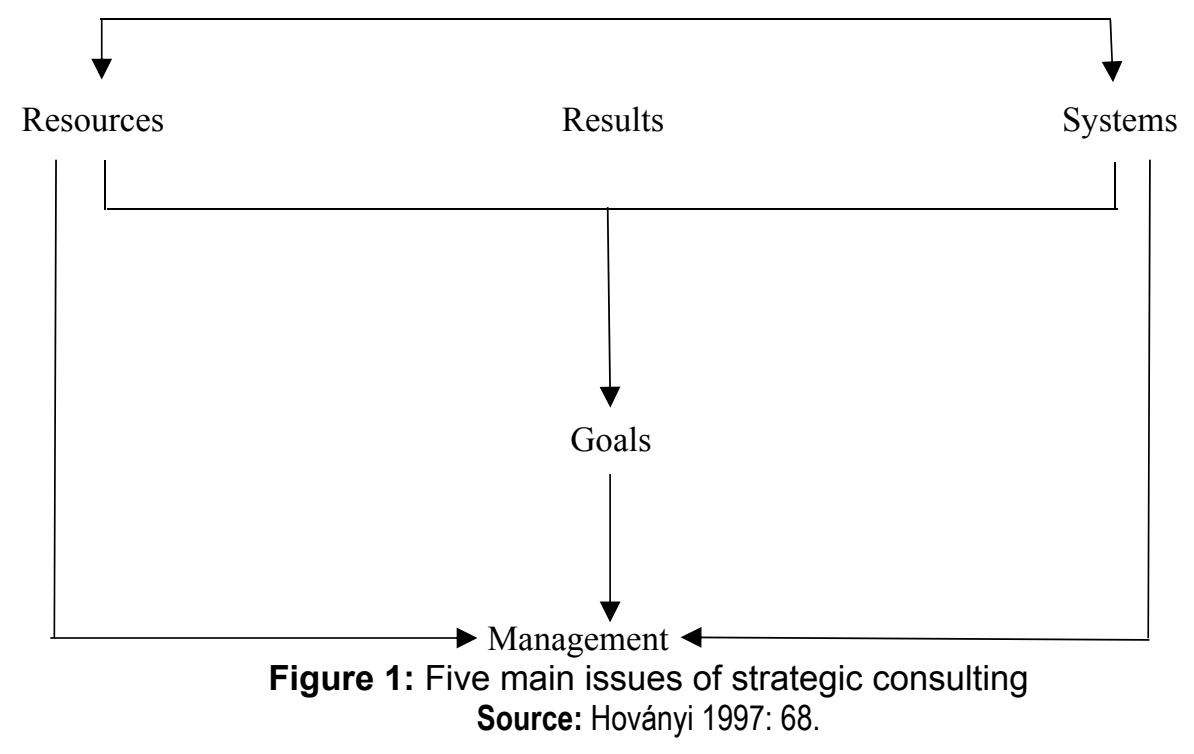

Ordinary company resources are capital, technology, human resources and natural resources. In a modern view these resources can be extended by six other resources: information, innovation potential, coordination, immaterial resources, fit in the vertical value chain and time (Hoványi 1999).

Systems stand for the functional parts and their cooperation inside the company. Companies are built up of smaller subsystems which should be synchronized with each other. Establishing knowledge transfers between companies in a supply-chain can help long-term quality, such as in case of Toyota and its suppliers (Dyer \& Singh 1998).

In case of results the most important are the quantified results which may be included in the company balance sheet and income statement. Consulting should help to develop the company in measurable results.

Results are directly connected to goals. Managers should have specified goals for the whole company and for the company subsystems as well. Goals may be outside the company as well: some organizations have social goals to achieve next to their own goals (Hoványi 1999).

Strategic consultants should help the company to reach competitive advantages. This can be based on company resources, systems, goals, results or leadership. The realized competitive advantage always depends on the features of the company and the environment, the strong and weak points of the competitors. Competitive advantage should be built in fields which are durable and the skill developing costs are low compared to the positive outcome of the advantage (Hoványi 1999).

\section{QUALITY ASSURANCE IN STRATEGIC MANAGEMENT CONSULTING}

Managing quality is particularly important in the business consulting industry because getting new contracts is not an easy task considering the intangible nature of consulting services and the fact that the result usually can not be seen immediately (Crăciun 2013).

One way to achieve quality is to work with the ten dimensions of quality in mind. This can be considered as a base, but this can not guarantee the appropriate result of a consulting project.

One side of quality is the technical quality which conforms with technical standards (Kubr 2002). Most of the consultant companies meet the requirements of this technical quality but their customers may not be happy with their consulting services. Customer satisfaction is a must in this industry which is mainly based on trust. As the outcome of the consulting services can not be guaranteed, organizations decide on new contracts based on their previous experiences (Mártonffy 2009). A good strategy can not be proved in advance, so there may be doubt in believing its success before its implementation (Bao 2015). In case an organization is not satisfied with the consultant it will probably look for other consulting company next time. Satisfied customers have several advantage in long term:

1. satisfied customers may became customers again,

2. deepen their relationship with the company,

3. have less price sensitivity,

4. recommend the services to other people or organizations (Kotelnikov 2020).

Management consulting firms have to build trust. The client has contract with the consulting firm and not with its individual employees so each worker in the organization has his/her role in building trust (Kubr 2002). The main way to achieve this to employ people with highly professional consulting skills. This is the role of human resource management (Karolinyné-Poór 2016). However this is expensive. Personnel training and motivation can also build skills and cause quality improvement (Crăciun 2013). Some of the generally used methods of quality control can not be used in case of business consulting. For example there can not be secret shoppers in this case. Measurements are hard to achieve. Evaluating suppliers, who may be consultant people can be done only after experience with working them. However there 
are techniques that can be used. Consultants can use customer surveys to measure the customer satisfaction and identify problematic points in the value chain. It is important to have a continuous feedback loop (Center for the Study of Social Policy 2017). The organization should become a learning organization:

1. Leadership should be committed to learning;

2. Reflection should be built into daily routines,

3. Experiences should be converted to practical knowledge;

4. Collect and process experiences should be done together with the colleagues;

5. Innovation should become from inside based on the knowledge and not by joining external innovations. (Kerekes et al 2011).

Building an excellent customer relationship between the consulting firm and the customer can provide higher value to the customer than they expected. This gives the feel of a higher quality service and can result in new contacts (Biech 2006). Quality can be achieved by using the ISO 9001 quality management standard. Traditionally quality management had eight basic values (Schmuck 2010). Two of them were joined together with the latest modification of the ISO 9001 standard in 2015. Because of this now there are seven quality management principles. These are the following:

1. Customer focus;

2. Leadership;

3. Engagement of people;

4. Process approach;

5. Improvement;

6. Evidence-based decision making;

7. Relationship management.

Using these basic principles ensure that the company operates by quality management standard meaning that the operations are well documented and the decisions are based on actual data analysis. Operations conforming the ISO 9001 quality management standard also ensure that the organization has customer satisfaction in its focus and it is continually trying the increase its processes and quality. In long term this should result in the growth of quality.

Consulting companies can use methods to increase their quality as well. Mostly soft methods can be used because of the limited availability of possible statistical data. The Japanese $5 \mathrm{~S}$ method can help to increase work productivity and decrease faults by helping to build a work environment both physically and mentally. This makes the first impressions of the customers better and increase the work morale of employees. (Dézsán 2007) The 5S are the following (in brackets the original Japanese words):

1. Sort (Seiri): Selecting and determining the needed objects for work and removing anything that is not needed;

2. Set In Order (Seiton): Correct layout of the selected objects;

3. Shine (Seiso): The cleanness, order and beauty of the workplace;

4. Standardize (Seiketsu): Using the previous three by everyone in the organization;

5. Sustain (Shitsuke): Esteem of organizations values and follow expected behavioral patterns within the organization (Schmuck 2010).

5S can be extended to 6S, which fosters a culture for continuous improvement and employee engagement (Gratiela 2012). Using brainstorming can also help the quality of organizations (Dézsán 2007). Brainstorming are among the top practices of gaining new ideas, mind-mapping can help to structure these (Abbas 2020, Hellmann \& Yiu 2013). In brainstorming people have a meeting to gather ideas and make decisions on a predefined problem or subject. Special team meeting can be done in quality. Quality circles have the role to solve quality problems in the organization (Titkos 1998).

Many of the consulting firms operate ISO 9001 standard-based quality management systems or TQM in their own organizations. Back in time this was a different story. In the 1980 s consulting firms rather worked on their clients' quality concerns not on their own. This has change a lot since that. Nowadays there is so high need of quality operation with reduced costs that the consulting firms themselves also operate quality management systems. These systems can reduce costs as well by making better decisions and decreasing the cost of bad quality such as faulty products and guarantee costs. (Schmuck 2010).

\section{CONCLUSIONS}

Quality is becoming a major issue for consulting companies to get new contracts. This is an industry based mainly on trust because the outcome of the service is not immediate and can hardly be measured. Consulting companies should not only keep the technical standards but have to satisfy the customers' requirements to provide a quality service. The service wheels explains why customer satisfaction is very important. Building trust is a major issue. Using appropriate human resource techniques and the $5 \mathrm{~S}$ method can help to achieve this. Brainstorming technique can also help. Quality can also be managed by the ISO 9001 quality management standard. Many of the consulting firms use this standard or the TQM management method. 


\section{REFERENCES}

Abbas, J. (2020). Impact of Total Quality Management on Corporate Sustainability through the Mediating Effect of Knowledge Management. Journal of Clearer Production, 244, 118806

Arnold, C., Bernstein, S. C. (2006). A stratégiatervezés mint belső tanácsadás. In Biswas,-Twitchell (editor): Menedzsment tanácsadás: Teljes körü útmutató az üzletághoz. Pécs: VHE.

Bao, G. (2015). What Theories are Needed for Strategic Management? Nankai Business Review International, 6(4), 433454.

Biech, E. (2006). A tanácsadás világa: VHE Kft, Pécs, Hungary

Biswas, S., Twitchell, D. (2006). Menedzsment tanácsadás: Teljes körü útmutató az üzletághoz. Pécs: VHE.

Block, Peter (2000). Flawless Consulting. A Guide to Getting Your Expertise Used. Second Edition: San Francisco: Jossey-Bass/Pfeiffer

Center for the Study of Social Policy (2017). Customer Satisfaction: Improving Quality and Access of Services and Supports in Vulnerable Neighborhoods: Washington DC

Collins, J. C., Porras, J. I. (1996). Building Your Company's Vision. Harvard Business Review, 1996(SeptemberOctober) 65-76.

Crăciun, C.S. (2013). Quality of Business Consulting Services. International Journal of Academic Research in Economics and Management Sciences, 2(1), 53-58

Dézsán, I (2007). Minőségbiztosítás: A minőségirányítás alapjai: Budapest: Nemzeti Tankönyvkiadó

Dyer, J. H., Singh, H. (1998). The Relational View: Cooperative Strategy and Sources of Interorganizational Competitive Advantage. Academy Management Review, 23(4), 660-679.

Garvin, D. A. (1987). Competing on the Eight Dimensions of Quality. Harvard Business Review, 1987(NovemberDecember) 101-109.

Gratiela, B. D. (2012). Study Case: Yellow Tag vs. Quality Management. Procedia Social and Behavioral Sciences, 62, 313-318.

Hellman P., Liu Y. (2013). Development of Quality Management Systems: How Have Disruptive Technological Innovations in Quality Management Affected Organizations? Kvalita Inovácia Prosperita / Quality Innovation Prosperity, 17(1), 104-119.

Hoványi, G. (1997). Menedzsment tanácsadás. Pécs: Janus Pannonius Tudományegyetem Közgazdaságtudományi Kar.

Karoliny, M \& Poór, J (2016). Emberi erőforrás menedzsment kézikönyv: Budapest: Wolter Kluwer

Ittner, C. D., Larcker, D. F. (1997). Quality Strategy, Strategic Control Systems, and Organizational Performance. Accounting, Organizations and Society, 22(3/4), 293-314.

Kerekes, G.; Simon, I.; Szép, L. edited (2011). FEMIP könyvek sorozata: Nemzetközi és hazai bevált gyakorlatok a minőségfejlesztésben: Oktatáskutató és Fejlesztő Intézet, Hungary

Kotelnikov, V. (2020). Customer Satisfaction: The Prime Concern of Your Business and the Critical Component of Its Profitability. http://www.1000ventures.com/business_guide/crosscuttings/customer_satisfaction.html, accessed 8th February 2020

Kubr, M. (2002). Management Consulting: A Guide to the Profession. Forth Edition: Geneva: International Labour Office

Maria, A., Little, A. D. (2006). Tanácsadás a változásmenedzsment területén. In Biswas-Twitchell: Menedzsment tanácsadás: Teljes körü útmutató az üzletághoz. Pécs: VHE.

Mártonffy, A. (2009). A tanácsadó és a svindler. ITBusiness. http://www.ttbusiness.hu/Fooldal/main_flash_banner/A_tanacsado_es_a_svindler.html, accessed 8th February 2020

Miller, D., Whitney, J. O. (2003). Beyond Strategy: Configuration as a Pillar of Competitive Advantage. Business Horizons, 42(3), 5-17.

Moussetis, R. (2011). Ansoff Revisited: How Ansoff Interfaces with Both the Planning and Learning Schools of Thought in Strategy. Journal of Management History, 17(1), 102-125.

Senior, B \& Swailes, S. (2016). Organizational Change. Fifth Edition: FT Publishing International, UK

Schmuck, R. (2010). A minőségirányitás alapjai. Pécs: Comenius Kiadó

Steele, F. (1975). Consulting for Organizational Change: Amherst (MA): University of Massachusetts Press 
Svasta, M. (2010). Consultant în România. Profesia şi piaţa de consultanţă în management din România. Bune practici în consultanţă în management. Bucharest: A.M.C.O.R. Publishing

Sziszkov, V. I. (1975). A termékminőség közgazdasági-statisztikai mérése: Budapest: Közgazdasági és Jogi Könyvkiadó

Zeithaml, V. A., Parasurman, A.; Berry, L. L. (1985). A Conceptual Model of Service Quality and Its Implications for Future Research. The Journal of Marketing, 49(4), 41-50.

Viadiu, F. M., Fa, M. C., Saizarbitoria, I. H. (2002). Do Quality Consultants Offer a Quality Service? Total Quality Management, 13(6), 797-811.

Titkos, Cs. (1998). Csoportmunka a 90-es években. Pécs: Janus Pannonius Tudományegyetem Közgazdaságtudományi Kar

Vörös, J. (2010). Termelés- és szolgáltatásmenedzsment. Budapest: Akadémiai Kiadó 